\title{
Targeting liver myofibroblasts: a novel approach in anti-fibrogenic therapy
}

\author{
Angela Douglass $\cdot$ Karen Wallace $\cdot$ Matthew Koruth . \\ Caroline Barelle $\cdot$ Andrew J. Porter $\cdot$ Matthew C. Wright
}

Received: 26 February 2008/Accepted: 21 July 2008/Published online: 3 September 2008

(C) Asian Pacific Association for the Study of the Liver 2008

\begin{abstract}
Chronic liver disease results in a liver-scarring response termed fibrosis. Excessive scarring leads to cirrhosis, which is associated with high morbidity and mortality. The only treatment for liver cirrhosis is liver transplantation; therefore, much attention has been directed toward therapies that will slow or reverse fibrosis. Although anti-fibrogenic therapies have been shown to be effective in experimental animal models, licensed therapies have yet to emerge. A potential problem for any antifibrogenic therapy in the liver is the existence of the body's major drug metabolising cell (the hepatocyte) adjacent to the primary fibrosis-causing cell, the myofibroblast. This article reviews the development of a human recombinant single-chain antibody (scAb) that binds to the surface of myofibroblasts. This antibody binds specifically to myofibroblasts in fibrotic mouse livers. When conjugated with a compound that stimulates myofibroblast apoptosis, the antibody directs the specific apoptosis of myofibroblasts with greater specificity and efficacy than the free compound. The antibody also reduces the adverse effect of
\end{abstract}

A. Douglass $\cdot$ K. Wallace $\cdot$ M. C. Wright $(\bowtie)$ Institute of Cellular Medicine, School of Clinical \& Laboratory Sciences, University of Newcastle Upon Tyne, Level 2 William Leech Building, Medical School, Framlington Place,

Newcastle Upon Tyne NE2 4HH, UK

e-mail: M.C.Wright@ncl.ac.uk

A. Douglass $\cdot$ C. Barelle

Wyeth Research, Polwarth Building, Foresterhill, Aberdeen, UK

A. Douglass · M. Koruth · A. J. Porter

School of Medical Sciences, University of Aberdeen,

Aberdeen, UK liver macrophage apoptosis and-in contrast to the free compound-reversed fibrosis in the sustained injury model used. These data suggest that specifically stimulating the apoptosis of liver myofibroblasts using a targeting antibody has potential in the treatment of liver fibrosis.

Keywords C1-3 - Gliotoxin - Hepatic stellate cell · Fibrosis - Kupffer cell $\cdot$ Matrix metalloproteinase 13

\section{Introduction}

Fibrosis is a progressive disease characterised by the accumulation of scarring extracellular matrix proteins, which disrupt normal tissue architecture. As fibrosis worsens, tissue function is impaired and in vital organs such as the liver-in the absence of transplantationmorbidity and mortality results [1].

Fibrosis is caused by an expansion and an increase in the activity of fibroblast populations within the liver, whichin a chronic damage setting - secrete and promote the accumulation of extracellular matrix proteins [1]. Initial work identified quiescent hepatic stellate cells as a source of cells that cause fibrosis [2], through their trans-differentiation to myofibroblasts (classically identified using $\alpha$-smooth muscle actin, Fig. 1). However, more recently it has become clear that a distinct population of fibroblasts expand from the portal tract (periductal and portal), particularly when the region of damage is located to this part of the lobule (e.g. in response to cholestasis) [3]. In addition, it has emerged that both these cell populations originate, at least in part during chronic liver injury, from the bone marrow $[4,5]$ and that fibrogenic cells may even be generated through epithelial-mesenchyme transition $[6,7]$. 

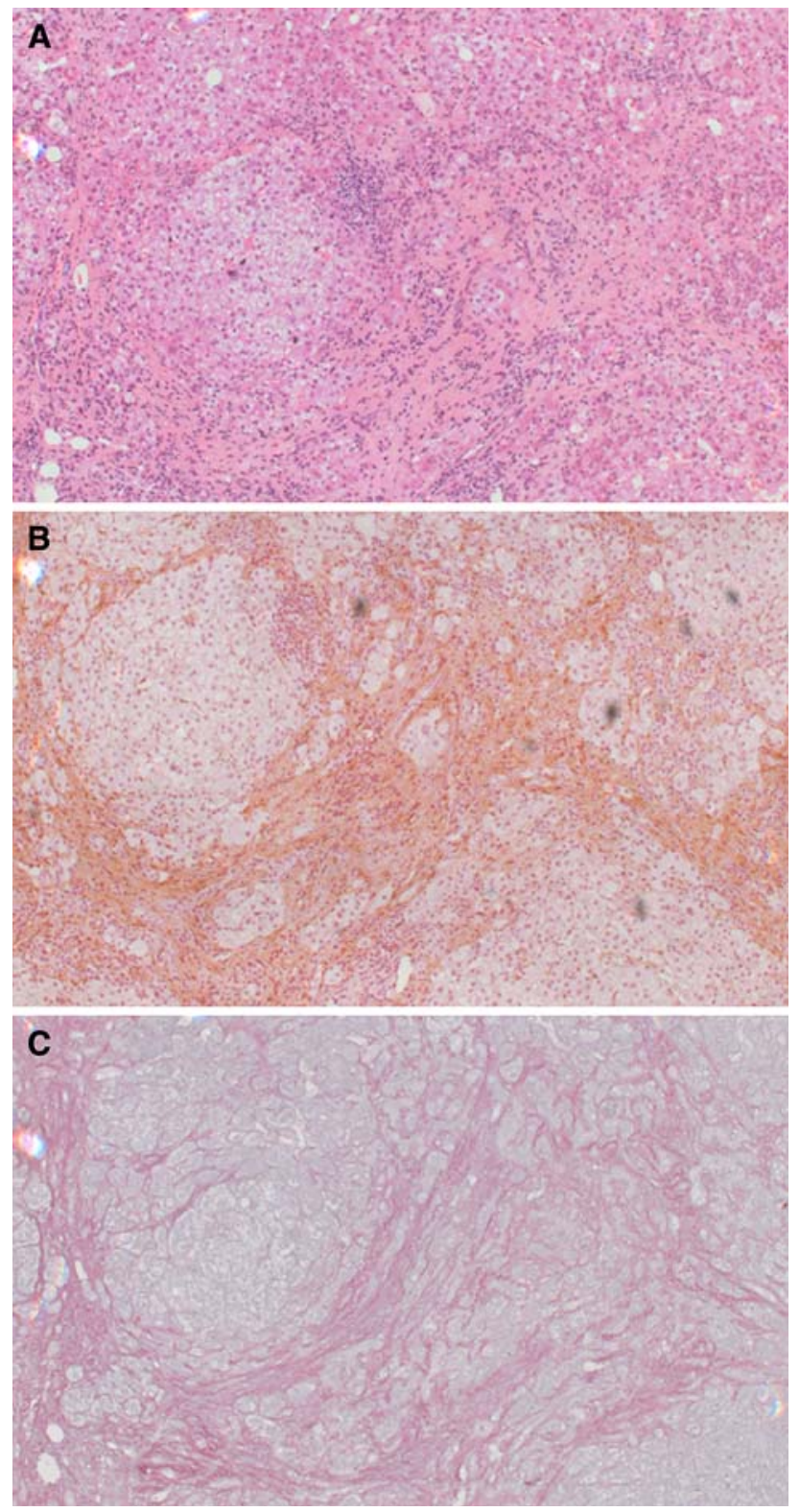

Fig. 1 Histology of the cirrhotic human liver. Serial liver sections from a liver biopsy were stained with (a) haematoxylin and eosin. (b) immunochemically with an antibody to $\alpha$-smooth muscle actin [11], brown staining indicates liver myofibroblasts. (c) Sirius red and haematoxylin [11], red staining indicates extracellular matrix deposition

\section{Current and future therapies}

At present, there are no therapies indicated for use as antifibrogenics in the liver. A major hurdle to the development of drugs for liver fibrosis is the requirement for prolonged treatment times to demonstrate efficacy in clinical trials. Trial length obviously imposes greater cost but an additional disincentive exists that there is more chance for adverse events to show during the trial. Failure in clinical drug trials has major implications for pharmaceutical companies and essentially dictates conservative investment decisions (particularly so in the case of liver disease, a high mortality area and an exclusion criterion for most therapeutic trials). A limited number of clinical trials are currently under way (for review see [1]); in many cases, however, existing drugs licensed for other indications (eg irbesartan and warfarin [1]) have been used. Novel compounds require pre-clinical and clinical safety testing and regulatory authorities require that any new drug must significantly benefit patients. There are fewer drugs emerging to the point of clinical trial as potential anti-fibrogenics. One example, however, is the farnesoid X receptor (FXR) activator 6-ethyl chenodeoxycholic acid (INT-747). This novel compound is known to inhibit both the trans-differentiation of human hepatic stellate cells to myofibroblasts in vitro and the development of fibrosis in animal models [8]. INT-747 is currently undergoing safety testing in persons with type 2 diabetes with presumed fatty liver for safety and tolerability [1].

In vitro models of liver fibrosis (the spontaneous transdifferentiation of hepatic stellate cells to myofibroblasts in culture [1]) and a range of in vivo animal models have aided the identification of potential therapeutic approaches for the treatment of liver fibrosis. Figure 2 illustrates the major parameters affecting myofibroblast activity and Table 1 lists some of the drug targets for therapeutic intervention.

A striking diversity of signalling pathways is available for pharmacological intervention in myofibroblasts. However, since recovery from fibrosis is accompanied by the apoptosis of liver myofibroblasts [9], this laboratory has concentrated on studying the effects of stimulating the apoptosis of fibrogenic cells in the liver as a potential therapeutic approach for liver fibrosis.

The fungal metabolite gliotoxin had originally been shown to stimulate the apoptosis of leucocytes [10]. Gliotoxin also stimulated the apoptosis of rat and human hepatic stellate cells and liver myofibroblasts in vitro [11, 12]. The effects of gliotoxin in an animal model of liver fibrosis recovery (i.e. gliotoxin was administered after the final liver insult and the effects on the rate of fibrosis reversal were determined) indicated for the first time that a promotion of myofibroblast apoptosis enhanced the resolution of fibrosis [11]. However, directing cell death as a mode of treatment for a disease comes with risk because most therapeutics are unlikely to act specifically on the target cells alone. The risk is therefore the stimulation of cell death in cells other than the target cells, with potential adverse effects.

\section{Targeting myofibroblasts}

A number of targeting strategies are being evaluated for their ability to selectively deliver therapeutics to liver myofibroblasts. These include modifying drug-carrying 
Fig. 2 Schematic diagram outlining the major parameters affecting the severity of liver fibrosis and the major points at which potential anti-fibrogenic therapeutics intervene. Numbers refer to numbering for "mode of action" as given in Table 1 . Inhibition, T; promoters, $\uparrow$

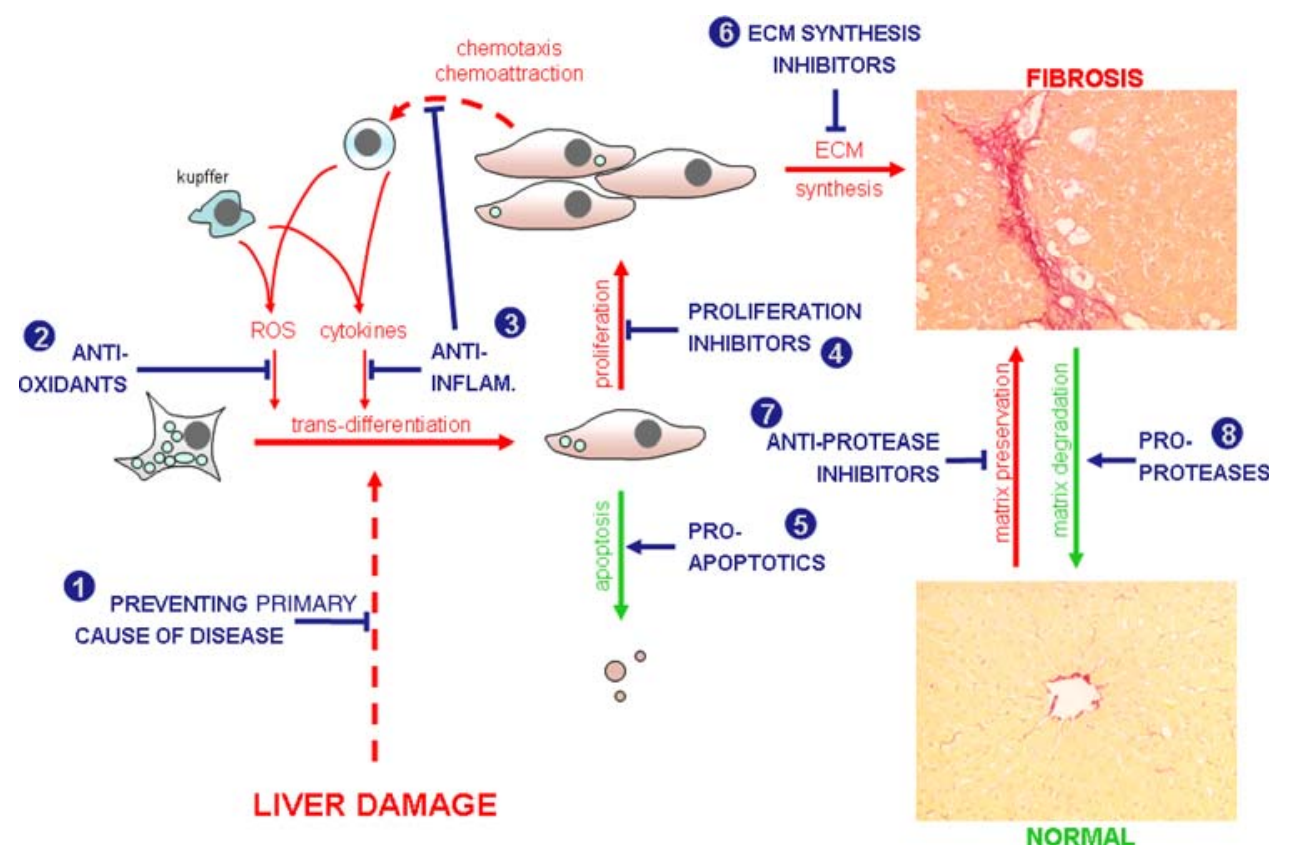

proteins with mannose-6-phosphate for uptake via the insulin-like growth factor II receptor [13], and with peptides that recognise the collagen type VI [14] or plateletderived growth factor [15] receptors.

This article reviews the generation of a human recombinant single-chain antibody (scAb-termed C1-3 [16]) to an extracellularly exposed region of synaptophysin, a plasma membrane protein expressed in the liver, specifically in human and rodent myofibroblasts [17]. Synaptophysin is primarily associated with neural tissue and is thought to be involved in synaptic vesicle exo-endocytosis. However, synaptophysin knockout mice show no phenotype or detectable effects on synaptic transmission [18]. An advantage of using synaptophysin as a target to deliver therapeutics is that this protein forms part of an endocytosing vesicle, increasing the likelihood for significant $\mathrm{scAb}$ and conjugated therapeutic uptake in myofibroblasts.

\section{Phage display}

Phage display is a powerful technique for selecting and cloning sequences that encode proteins with a native affinity for a particular ligand $[19,20]$. In the case of C1-3, a phage library was employed in which potentially the entire human repertoire of variable heavy and variable light chains (which encode antibody antigen-binding sites) were cloned as single fused domains into the pIII M13 bacteriophage coat protein gene (Fig. 3a). Each phage "displays" a variable domain on its surface, with typically $>10^{7}$ different clones comprising a phage display library. Variable domains that interact with a particular antigen (for $\mathrm{C} 1-3$, the antigen is the peptide 2 sequence-see Fig. 4) can be selected by a process of "panning", whereby the phage is exposed to an immobilised target sequence. Unbound phage is removed by washing and bound phage is eluted and amplified through re-infection of Escherichia coli (Fig. 3b). The process of panning is repeated several times allowing for the isolation of specific high-affinity antigen-binding phage. Single clones are then isolated and analysed prior to subcloning heavy and light chain-encoding regions into an expression vector that generates a single-chain protein (i.e. $\mathrm{scAb}$ ) fused in frame with other domains that facilitate detection and purification. Using established procedures, such as protein tagging, high levels of pure monoclonal $\mathrm{scAb}$ can be generated with relative ease.

\section{C1-3 scAb}

A range of human recombinant scAbs were generated to synaptophysin by phage display [16]. One of these, C1-3, was selected and its ability to act as a targeting agent for liver myofibroblasts was examined. Fluorescently labelled C1-3 scAb avidly bound to human myofibroblasts (Fig. 5) but not human hepatocytes [16]. The C1-3 was taken up into myofibroblasts through pinocytosis and alone was not toxic to myofibroblasts in vitro, but when conjugated with tributyl tin, the scAb directed the toxin to myofibroblasts (with toxin activity retained) [16].

Mice with liver fibrosis (via carbon tetrachloride administration) were injected intraperitoneally with C1-3 
Table 1 The major drug targets for potential anti-fibrogenic drugs

\begin{tabular}{|c|c|c|}
\hline Mode of action & Targeting & Potential therapeutic agents and comments \\
\hline $\begin{array}{l}1 \text { Preventing primary } \\
\text { cause of disease }\end{array}$ & & $\begin{array}{l}\text { Undoubtedly, preventing or curing the primary cause of disease is the best way to prevent or treat } \\
\text { liver fibrosis. Anti-fibrogenics are required when the primary cause of disease is not } \\
\text { successfully treated. }\end{array}$ \\
\hline 2 Antioxidants & $\begin{array}{l}\text { Reactive oxygen } \\
\text { species released } \\
\text { from inflammatory } \\
\text { cells (also possibly } \\
\text { myofibroblast } \\
\text { proliferation). }\end{array}$ & $\begin{array}{l}\mathrm{N} \text {-acetyl cysteine [31, 32], resveratrol [32], quercetin [32]. Note, quercetin is also a WNT } \\
\text { signalling inhibitor (Tcf/Lef inhibitor) [33] and a repression of WNT signalling has been } \\
\text { associated with trans-differentiation to myofibroblasts [34, 35]. Vitamin E [36], evidence of } \\
\text { anti-fibrogenic effects in patients with NASH treated with vitamins C and E [37]. Angiotensin } \\
\text { II inhibitors-via inhibiting the activation of NADPH oxidase mediated by angiotensin II [38]. }\end{array}$ \\
\hline \multirow[t]{3}{*}{$\begin{array}{l}3 \text { Anti-inflammatory } \\
\text { agents }\end{array}$} & $\begin{array}{l}\text { Glucocorticoid } \\
\text { receptor }\end{array}$ & $\begin{array}{l}\text { Glucocorticoid agonists often administered to inhibit inflammation, particularly in immune- } \\
\text { mediated hepatitis [39]. May not have any direct effects on fibrosis [40] but dexamethasone has } \\
\text { been noted to inhibit TGF } \beta \text { expression in liver myofibroblasts in vitro [41]. Note, Kupffer cell- } \\
\text { targeted glucocorticoids lead to increased levels of fibrosis in experimental animal models [42]. }\end{array}$ \\
\hline & Cyclooxygenase & $\begin{array}{l}\text { Cyclooxygenase (COX) inhibitors inhibit the production of leukotrienes and prostaglandins, e.g. } \\
\text { COX2 inhibitor JTE-522 [43]. However, hepatic COX2 knockout or overexpression in } \\
\text { transgenic mice is reported to have no effects on liver fibrosis [44]. }\end{array}$ \\
\hline & $\mathrm{NF}-\kappa \mathrm{B}$. & $\begin{array}{l}\text { NF- } \kappa \text { B inhibitors (e.g. sulfasalazine [45]). However, primary effects believed to be mediated via } \\
\text { apoptosis (see 5). }\end{array}$ \\
\hline \multirow[t]{12}{*}{$\begin{array}{r}4 \text { Proliferation } \\
\text { inhibitors }\end{array}$} & $\begin{array}{l}\text { Peroxisome } \\
\text { proliferator } \\
\text { activated receptor- } \\
\gamma(\operatorname{PPAR} \gamma) \text {. }\end{array}$ & $\begin{array}{l}\operatorname{PPAR} \gamma \text { agonists—-such as anti-diabetic thiazolidones (e.g. troglitazone, rosiglitazone, } \\
\text { pioglitazone-inhibit trans-differentiation/proliferation of myofibroblasts in vitro [46, 47]. } \\
\text { PPAR } \gamma \text { is expressed in hepatic stellate cells but falls rapidly in primary culture as the cells } \\
\text { trans-differentiate to myofibroblasts [47]. }\end{array}$ \\
\hline & & $\begin{array}{l}\text { Farglitazar is completing an anti-fibrogenic trial in patients with chronic hepatitis } \mathrm{C}[1] \text {. Curcumin } \\
\text { effects may also function via PPAR } \gamma[48] \text {. }\end{array}$ \\
\hline & $\begin{array}{l}\text { Farnesoid X receptor } \\
\quad \text { (FXR). }\end{array}$ & $\begin{array}{l}\text { FXR activator synthetic bile acid INT-747 is anti-fibrogenic [8] although effects could also be } \\
\text { mediated via PXR since this related receptor also ligands bile acids [49]. Currently undergoing } \\
\text { clinical trial [1]. }\end{array}$ \\
\hline & $\begin{array}{l}\text { Pregnane-X receptor } \\
\text { (PXR). }\end{array}$ & $\begin{array}{l}\text { PXR ligands (e.g. rifampicin, hyperforin) inhibit proliferation and ECM synthesis [50, 51]. } \\
\text { Rifampicin is often given to patients with primary biliary cirrhosis (to control itch) and has } \\
\text { been shown to reduce serum levels of alkaline phosphatase in patient trials [52, 53]. However, } \\
\text { its effects on fibrosis have not been examined. Ursodeoxycholate is also a PXR activator [54]. } \\
\text { This compound is also given to patients with primary biliary cirrhosis and has been reported to } \\
\text { reduce progression to cirrhosis [55]. }\end{array}$ \\
\hline & $\begin{array}{l}\text { Renin-angiotensin } \\
\text { system }\end{array}$ & $\begin{array}{l}\text { Liver myofibroblasts synthesise angiotensin, which acts in an autocrine manner to promote } \\
\text { fibrosis [56]. Angiotensin II R1 antagonists (e.g. losartan) inhibit proliferation and also ECM } \\
\text { synthesis [57] and have been reported to reduce fibrosis in clinical trails [58]. The angiotensin } \\
\text { II R1 antagonist irbesartan is currently undergoing clinical trials [1]. Angiotensin-converting } \\
\text { enzyme (ACE) inhibitors are also potential therapeutics, (e.g. perindopril [59]). }\end{array}$ \\
\hline & Phosphodiesterase & $\begin{array}{l}\text { Pentoxifylline has been shown to inhibit liver fibrosis in animal models [60,61]. Pentoxifylline is } \\
\text { an inhibitor of phosphodiesterases, leading to increased intracellular levels of cyclic adenosine } \\
\text { monophosphate (cAMP) [62], but may act by other mechanisms [63]. Undergoing clinical trials } \\
\text { for survival rate in patients with cirrhosis [1]. }\end{array}$ \\
\hline & MAP kinase & $\begin{array}{l}\text { Salvianolic acid [64], but may have other targets [65]. Reported to inhibit fibrosis in a cohort of } \\
\text { patients with hepatitis B [66]. }\end{array}$ \\
\hline & Unknown & $\begin{array}{l}\text { Pirfenidone [67]. In relation to the mechanism of the anti-fibrotic action, pirfenidone has been } \\
\text { shown to modify cytokine regulatory actions, inhibit fibroblast proliferation and collagen } \\
\text { matrix synthesis. Shown to be effective in clinical trials [1]. Halofuginone inhibits } \\
\text { myofibroblast proliferation by unknown mechanism [68,69] and also by other mechanisms } \\
\text { (see } 6 \text { and 8). }\end{array}$ \\
\hline & CB1 receptor & $\begin{array}{l}\text { CB1 receptor is expressed in myofibroblasts and promote fibrosis [70]. CB1 antagonism (e.g. via } \\
\text { SR141716A/rimonabant) inhibits fibrosis [70], also increases myofibroblast apoptosis [70]. }\end{array}$ \\
\hline & CB2 receptor & $\begin{array}{l}\text { CB2 receptor agonists (e.g. } \Delta 9 \text {-tetrahydrocannabinol [71]). Note, however, that daily cannabis } \\
\text { smoking is associated with fibrosis progression [72]. }\end{array}$ \\
\hline & Opioid receptor & Opioid receptor antagonists (e.g. naltrexone [73]). \\
\hline & $\begin{array}{l}\text { Serotonin }(5 \mathrm{HT}) \\
\quad \text { receptor }\end{array}$ & $\begin{array}{l}\text { Rodent and human myofibroblasts express several } 5 \mathrm{HT} \text { receptor sub-types; } 5 \mathrm{HT}_{2} \text { antagonists are } \\
\text { anti-fibrogenic (e.g. methiothepin maleate or spiperone [74]). Also increases myofibroblast } \\
\text { apoptosis [74]. }\end{array}$ \\
\hline
\end{tabular}


Table 1 continued

\begin{tabular}{|c|c|c|}
\hline Mode of action & Targeting & Potential therapeutic agents and comments \\
\hline \multirow[t]{4}{*}{5 Pro-apoptotics } & $\mathrm{NF}-\kappa \mathrm{B}$ & $\begin{array}{l}\text { Through inhibition of activation via IKK inhibition (e.g. sulphasalazine [45]), also proteasomal } \\
\text { inhibitors [75]. Note, human liver myofibroblasts may become more resistant to proteasomal } \\
\text { inhibitors with time [76]. Gliotoxin inhibits NF- } \kappa \text { B via proteasomal inhibition [12], however, it } \\
\text { also targets mitochondria [45], which may explain its potency at stimulating human } \\
\text { myofibroblast apoptosis }[11,76] \text { and inhibition of fibrosis in vivo }[11,21] \text {. }\end{array}$ \\
\hline & RS kinase & $\begin{array}{l}\text { RS kinase inhibition promotes myofibroblast apoptosis and inhibits liver fibrosis in animal models } \\
\text { [77]. }\end{array}$ \\
\hline & $\begin{array}{l}\mathrm{CB} 1 \text { and } \mathrm{CB} 2 \\
\text { receptors (see 4) }\end{array}$ & \\
\hline & $\begin{array}{l}\text { 5HT receptors } \\
\quad(\text { see } 4)\end{array}$ & \\
\hline $\begin{array}{l}6 \text { ECM synthesis } \\
\text { inhibitors }\end{array}$ & TGF $\beta$ & $\begin{array}{l}\text { TGF } \beta \text { antagonism (e.g. decoy soluble TGF } \beta \text { receptor [78]), However, TGF } \beta \text { may be critical for } \\
\text { other tissues and may be a tumour supressor [79]. Inhibitors of proteolytic TGF } \beta \text { activation } \\
\text { (e.g. camostat mesilate [80]). Halofuginone [81]. }\end{array}$ \\
\hline $\begin{array}{l}7 \text { Anti-protease } \\
\text { inhibitors }\end{array}$ & $\begin{array}{l}\text { Tissue inhibitors of } \\
\text { metalloproteinases } \\
\text { (TIMP). }\end{array}$ & Polaprezinc down regulates TIMP1 and 2 expression [82]. Antagonistic antibodies [83]. \\
\hline 8 Pro-proteases & & $\begin{array}{l}\text { uPA via adenoviral gene therapy in animal model [84]. Halofuginone increases fibrolytic MMP } \\
\text { expression }[69,85] \text {. }\end{array}$ \\
\hline
\end{tabular}

The table outlines some of the potential anti-fibrogenic drug targets for which potential therapeutic agents are already available. There are additional pathways for which either intervention remains unexploited or information is not freely available. These include intervening in adiponectin signalling, which suppresses PDGF-dependent myofibroblast proliferation and fibrosis in experimental animal models [86], and leptin, which is synthesised by myofibroblasts [87] and promotes fibrosis [88]

$\mathrm{scAb}$ to determine its effectiveness as a drug-targeting agent in vivo [21]. Initial studies used fluorescently labelled C1-3 to examine its distribution throughout the body up to $24 \mathrm{~h}$ after injection. The results of these studies showed that the $\mathrm{C} 1-3 \mathrm{scAb}$ appeared in the serum within $20 \mathrm{~min}$ and was eliminated with an approximate half life of $2 \mathrm{~h}$

A
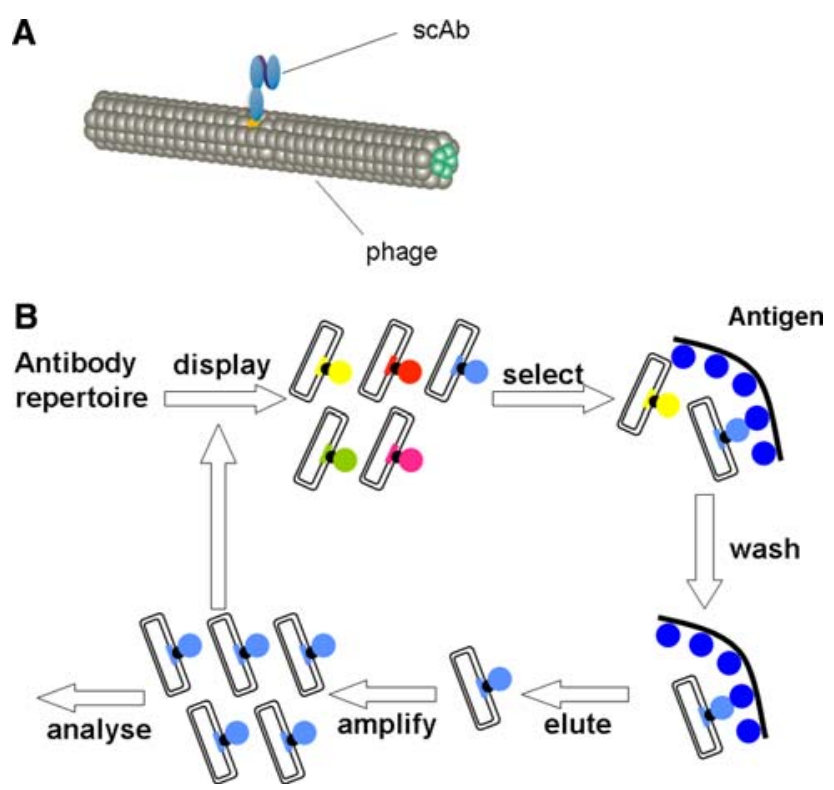

Fig. 3 (a) Schematic diagram of recombinant M13 bacteriophage incorporating an $\mathrm{scAb}$ within its coat protein. (b) Schematic diagram outlining the procedure of phage display
[21]. The C1-3 scAb was detectable in liver homogenate but undetectable in brain, muscle or spleen [14]. Immunohistochemical analysis indicated that the $\mathrm{C} 1-3 \mathrm{scAb}$ localised to the liver, in regions where scars were present. There was minimal immunohistochemical evidence for the presence of $\mathrm{C} 1-3 \mathrm{scAb}$ in non-fibrotic liver [21]. Costaining of fibrotic liver sections showed that the C1-3 $\mathrm{scAb}$ colocalised with myofibroblast $\alpha$-smooth muscle actin, but not the monocyte and macrophage marker F4/80 [21]. These data indicate that the $\mathrm{C} 1-3 \mathrm{scAb}$ readily and selectively targeted liver myofibroblasts in an animal model of liver fibrosis.

To determine whether $\mathrm{C} 1-3$ could deliver a functional experimental anti-fibrogenic therapeutic agent to myofibroblasts, it was chemically conjugated with gliotoxin. Free gliotoxin has been shown in previous work to stimulate the apoptosis of liver myofibroblasts in vitro and in vivo and enhance recovery from liver fibrosis in vivo [11, 12, 22]. However, gliotoxin also causes-although to a lesser degree-the apoptosis of hepatocytes and stimulates Kupffer cell death [4, 17, 23, 24].

Gliotoxin was chemically conjugated to either a C1-3 $\mathrm{scAb}$ or a control CSBD9 scAb (selected for its ability to bind to an irrelevant ligand) using $\mathrm{N}$-[p-maleimidophenyl] isocyanate and S-acetyl thioglycolic acid N-hydroxysuccinimide [21] (for details also see online data: http://dx.doi.org/10.1016/j.jhep.2008.01.032). Conjugation did not significantly alter $\mathrm{scAb}$ affinities for their respective antigens (as determined using antigen ELISA and BIAcore 
Fig. 4 Schematic diagram of synaptophysin. Each circle represents an amino acid, with membrane-spanning residues determined using TMpred software [16]. Orange residues correspond to the antigen site for $\mathrm{C} 1-3$

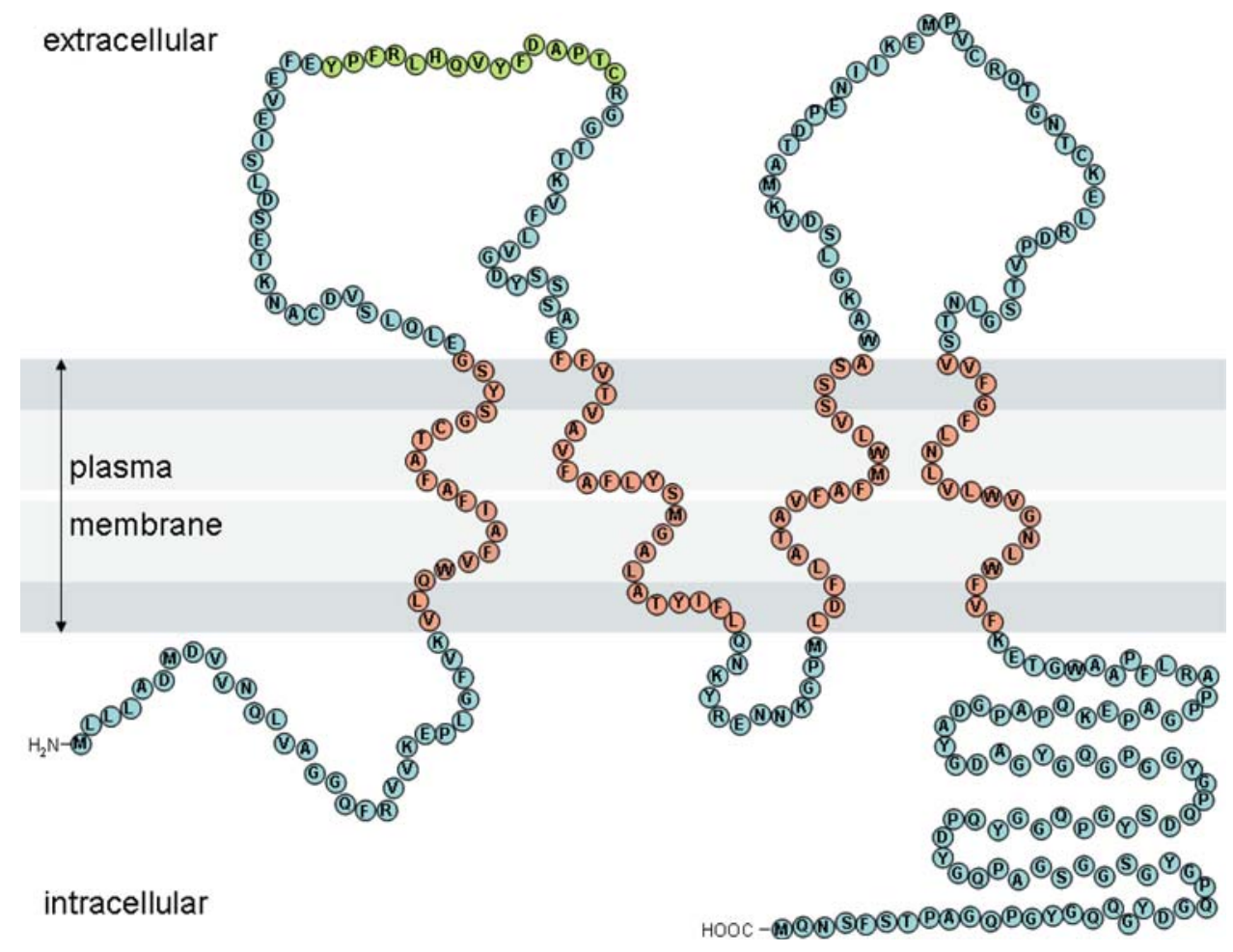

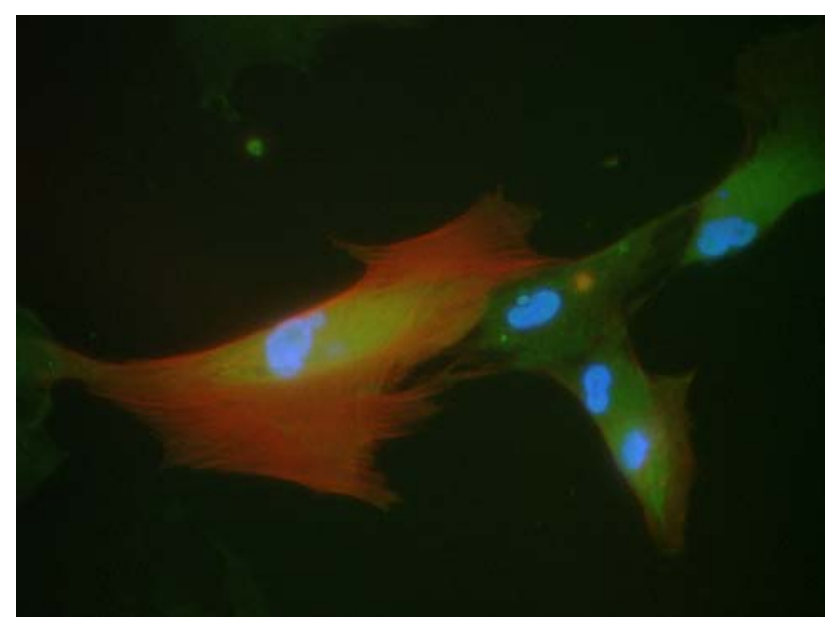

Fig. 5 Human liver myofibroblasts bind FITC-labelled C1-3 scAb (green). Hepatic stellate cells were isolated by pronase and collagenase perfusion from resected human liver and were cultured as outlined [11]. After transdifferentiation and sub-culture, cells were typically more than $95 \%$ positive for the classic myofibroblast marker $\alpha$-smooth muscle actin [1]. The panel shows a typical view of liver myofibroblasts after incubation with FITC-labelled C1-3 (green) in culture as outlined [16], followed by fixation and co-staining for the myofibroblasts marker $\alpha$-smooth muscle actin (red) and DNA using DAPI (blue)

[21]) or ablate gliotoxin's ability to cause liver myofibroblast apoptosis (see Figs. 6 and 7).

Mice were administered carbon tetrachloride twice weekly for 8 weeks to generate liver fibrosis. During the last week prior to the final injection of carbon tetrachloride,

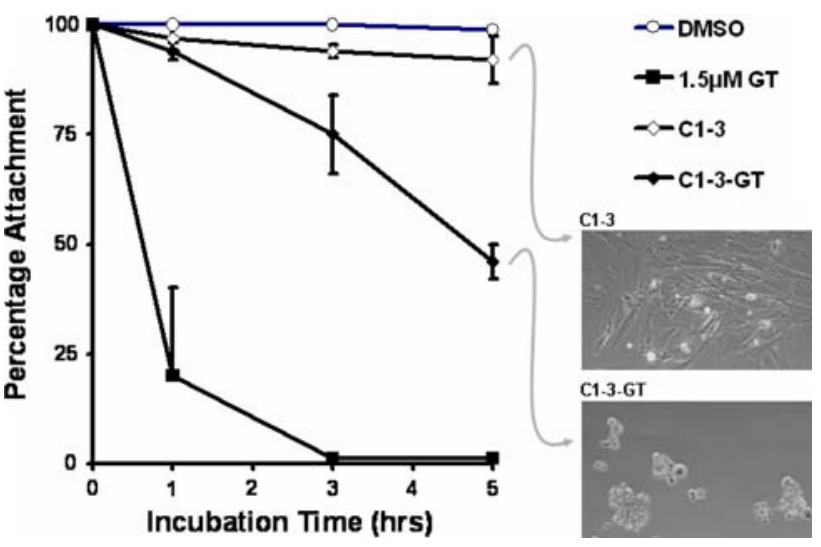

Fig. 6 Time course for the effects of free gliotoxin or C1-3-gliotoxin (C1-3-GT) on sub-stratum adherence in vitro. Human myofibroblasts (culture-activated hepatic stellate cells [11]) were sub-cultured into 24-well plates in $300 \mu \mathrm{l}$ of medium and treated with either free gliotoxin added from a 1,000-fold molar concentrated stock in DMSO vehicle (total 450 pmoles/well); $4.5 \mu \mathrm{g} \mathrm{C1-3/well} \mathrm{or} 4.5 \mu \mathrm{g} \mathrm{C1-3-}$ gliotoxin $\mathrm{scAb}$ (to give approximately 450 pmoles gliotoxin/well for conjugated $\mathrm{scAb}$ ). Data are the mean and standard deviation of 3 separate human cell preparations. Right panels, photomicrographs of typical views of cells at the indicated treatment after $5 \mathrm{~h}$

mice were treated with a single dose of C1-3 scAb or C1-3gliotoxin scAb. The mice were therefore treated with a potential therapeutic agent and injury was sustained by further treatment with carbon tetrachloride. Fibrotic mice were also treated with an equivalent dose of free gliotoxin or gliotoxin conjugated to CSBD9 (i.e. CSBD9-GT). 
Fig. 7 Time course for the effects of C1-3-GT on active caspase 3 levels in human myofibroblasts in vitro. Human myofibroblasts were cultured and treated with C1-3-GT essentially as outlined in Figure 5. At the indicated time points, cells were fixed and stained for $\alpha$-smooth muscle actin (red), active caspase 3 (green) and DNA using DAPI (blue). The active caspase 3 antibody was purchased from Promega (Southampton, UK). Results are typical of cells isolated from 3 individual patients

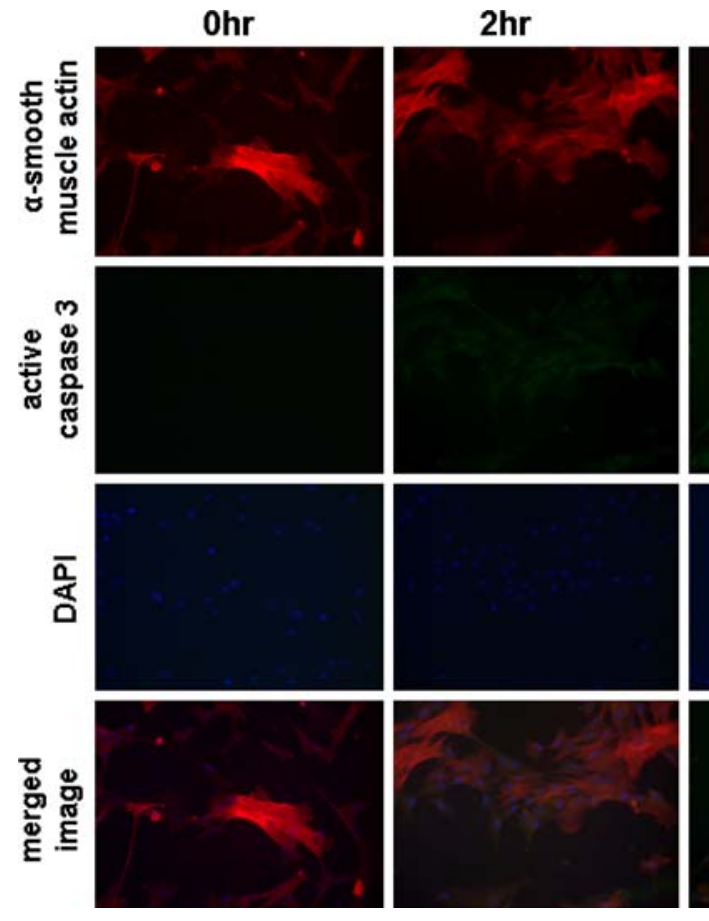

$6 \mathrm{hr}$
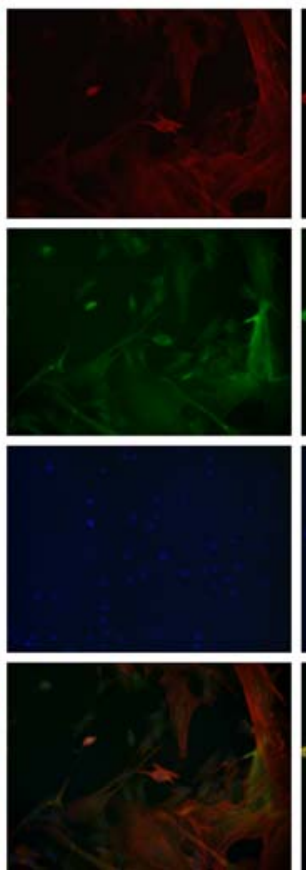

$24 \mathrm{hr}$
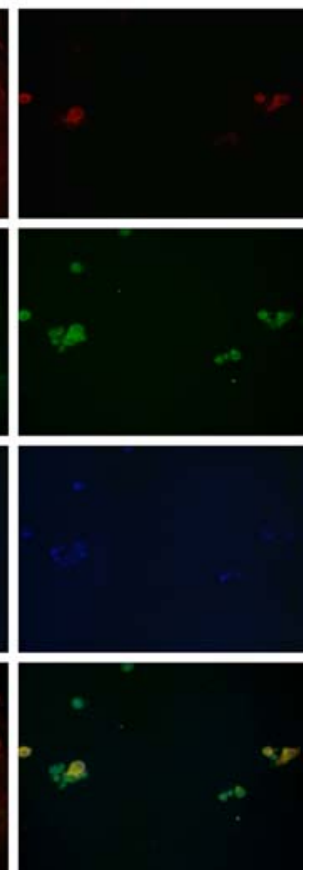

Table 2 The effects of gliotoxin and C1-3-gliotoxin on parameters of liver fibrosis in a sustained carbon tetrachloride model of liver fibrosis [21]

\begin{tabular}{|c|c|c|c|c|}
\hline Treatment & Number of myofibroblasts & Number of F4/80 cells & Fibrosis severity & MMP-13 levels \\
\hline DMSO vehicle & +++++ & +++ & ++++ & ++++ \\
\hline Free gliotoxin & $+++^{\mathrm{a}}$ & $++^{\mathrm{a}}$ & ++++ & $+++^{\mathrm{a}}$ \\
\hline PBS & +++++ & +++ & ++++ & ++++ \\
\hline \multicolumn{5}{|l|}{$\mathrm{C} 1-3$} \\
\hline C1-3-gliotoxin & $+^{\mathrm{b}}$ & +++ & $++^{\mathrm{b}}$ & ++++ \\
\hline CSBD9 & +++++ & +++ & ++++ & ++++ \\
\hline CSBD9-gliotoxin & +++++ & +++ & ++++ & ++++ \\
\hline
\end{tabular}

Mice were administered $\mathrm{CCl}_{4}$ over a 8 -week period as outlined [21] and the liver was examined for myofibroblasts via $\alpha$-smooth muscle actin immunostaining [11]; Kupffer cells by immunostaining for F4/80 [21]; fibrosis severity through histochemical staining with Sirius red [11]; and MMP-13 levels by immunohistochemistry [21]. Note, gliotoxin was administered in DMSO at a dose of $0.6 \mathrm{mg} / \mathrm{kg}$ body weight. ScAbs were administered in phosphate-buffered saline (PBS) at a dose of $20 \mathrm{mg}$ of protein/kg body weight. Mice received conjugates at an equivalent dose of $0.6 \mathrm{mg}$ of gliotoxin $/ \mathrm{kg}$ body weight. Data are blinded examination of staining intensity in liver sections from five animals per treatment groupsignificantly different (two tailed) from ${ }^{\mathrm{a}} \mathrm{DMSO}$ control or ${ }^{\mathrm{b}} \mathrm{PBS}$ control using Student's T test $(P>95 \%)$ [21]

The results are summarised in Table 2 and show that free gliotoxin reduced the number of myofibroblasts but did not reduce fibrosis severity in the liver. C1-3-gliotoxin more potently reduced the number of myofibroblasts present than the same dose of free gliotoxin and in addition significantly reduced the severity of fibrosis in the liver. C1-3 scAb, CSBD9 scAb and CSBD9-GT had no effect on the number of liver myofibroblasts or fibrosis severity. Interestingly, free gliotoxin reduced the number of F4/80 positive cells (i.e. monocytes and macrophages/Kupffer cells) and matrix metalloproteinase 13 levels in the liver, whereas C1-3-gliotoxin did not. Macrophage depletion abrogates recovery from liver fibrosis [25]. Retaining macrophages in C1-3-gliotoxin-treated animals may account for the improved anti-fibrogenic effect of gliotoxin when targeted to liver myofibroblasts with C1-3.

\section{Diagnostic and therapeutic perspectives}

Two major hurdles must be overcome to advance successful treatments for fibrosis. The first is the effective assessment of fibrosis in both experimental and clinical studies. It remains problematic to accurately screen for fibrosis using a battery of serum markers, particularly for those at early and intermediate stages of disease [26]. Biopsy remains the "gold standard" diagnostic tool for liver disease [27] but has significant drawbacks (the 
procedure is risky; repeated biopsy is inadvisable; and it does not give a globally accurate picture of organ fibrosis). The second hurdle is specificity and efficacy of potential treatments (in the liver, the myofibroblasts lie adjacent to the major drug metabolising cell of the body, the hepatocyte).

This laboratory has examined the potential of an antibody-based approach to tackle both imaging and therapeutic delivery in fibrosis. Although the C1-3 scAb does not directly bind to fibrosis proteins (it binds to the major fibrogenic cell), an image-visible scAb derivative may be effective in providing an indication of fibrosis severity. If successful as an imaging agent, experimental and clinical imaging studies should aid in its development as a targeting agent for anti-fibrogenic therapeutics.

The utility or therapeutic efficacy of whole antibody, or related antibody structures, in vivo is influenced by a number of competing factors. These include specificity, affinity (including avidity) and serum half life. The C1-3 has already been expressed successfully as a monomeric $\mathrm{scAb}(37 \mathrm{kDa})$. In addition, it could also be used in a slightly smaller but related $\mathrm{scFv}$ formulation $(25 \mathrm{kDa})$ or expressed as a dimeric fragment $(60 \mathrm{kDa}$, which will typically show one order of magnitude improvement in affinity for antigen through increased avidity). Finally, the C1-3 could be expressed as a full (150 kDa) mAb incorporating either a mouse or a human $\mathrm{Fc}$ region. This construct will have a similar affinity to the C1-3 dimer but an increased serum half life and the capacity to initiate cell killing upon binding in vivo.

Typically, for imaging agents, a shorter serum half life is favoured, to maximise signal-to-noise ratios in the diseased tissue. For therapeutic applications, a whole antibody is often preferred where antibody binding and presentation of the Fc region can recruit components of the mammalian immune system and induce cell killing. However, for certain applications, a smaller antibody fragment conjugated to a cell-killing agent may be a more potent therapeutic formulation. This type of agent can provide a powerful alternative to Fc-induced cell death, offering greater tissue penetration and rapid clearance of toxic drugs from nontarget tissues.

The administration of a recombinant antibody specific for the surface of liver myofibroblasts could be used to develop a safer, less invasive and more effective diagnostic tool for the assessment of fibrosis throughout the entire organ. In the short term, this could lead to more refined experimental animal studies; provide a more effective assessment of potential anti-fibrogenics; and reduce the number of animals required in pre-clinical studies. Experimental animal studies will also contribute to the translation of the diagnostic to the clinical reality in the long term, as part of in vivo imaging (diagnostic and diseases management). In addition, the C1-3 antibody could be used to direct anti-fibrogenics to the myofibroblasts (or analogous pro-fibrogenic cells in other tissues). Directing therapeutics specifically to the target myofibroblast - and away from other cells-will enhance the efficacy of an anti-fibrogenic since it will reduce the amount of therapeutic required and the likelihood of adverse effects. However, a drawback of using C1-3 is the potential effect on any cells that also express synaptophysin, particularly when the conjugated therapeutic mediates cell death. The major concern would therefore be neural and neuroendocrine cells. Although there is no evidence that the $\mathrm{C} 1-3$ scAb crossed the blood-brain barrier in animal studies [21], imaging studies should confirm whether this is the case. However, it should be borne in mind that there is currently no treatments available for use as anti-fibrotic in patients [28]. The major causes of liver fibrosis in the developed world are non-alcoholic steatohepatitis (NASH), hepatitis $\mathrm{C}$ infection and alcoholism. NASH has an incidence of at least $2 \%$ in the European Union and United States and the incidence of Hepatitis C infection is between $1 \%$ and $2 \%$ [29, 30]. The incidence of both of these diseases is predicted to rise in the future and further reinforces the urgent need to diagnose, manage and treat this "silent killer". It may be the case with some patients with cirrhosis - in whom there are no therapeutic options available-that an experimental and more risky approach may be needed in order to find effective treatments.

\section{References}

1. Wallace $\mathrm{K}$, Burt $\mathrm{AD}$, Wright MC. Liver fibrosis. Biochem $\mathbf{J}$ 2008;411:1-18. doi:10.1042/BJ20071570.

2. Friedman SL, Roll FJ, Boyles J, Bissell DM. Hepatic lipocytes: the principal collagen-producing cells of normal rat liver. Proc Natl Acad Sci USA 1985;82:8681-8685. doi:10.1073/pnas.82. 24.8681.

3. Beaussier M, Wendum D, Schiffer E, Dumont S, Rey C, Lienhart A, et al. Prominent contribution of portal mesenchymal cells to liver fibrosis in ischemic and obstructive cholestatic injuries. Lab Invest 2007;87:292-303. doi:10.1038/labinvest.3700513.

4. Baba S, Fujii H, Hirose T, Yasuchika K, Azuma H, Hoppo T, et al. Commitment of bone marrow cells to hepatic stellate cells in mouse. J Hepatol 2004;40:255-260. doi:10.1016/j.jhep. 2003. 10.012 .

5. Russo FP, Alison MR, Bigger BW, Amofah E, Florou A, Amin F, et al. The bone marrow functionally contributes to liver fibrosis. Gastroenterology 2006;130:1807-1821. doi:10.1053/j.gastro.2006. 01.036.

6. Zeisberg M, Yang C, Martino M, Duncan MB, Rieder F, Tanjore $\mathrm{H}$, et al. Fibroblasts derived from hepatocytes in liver fibrosis via epithelial to mesenchymal transition. J Biol Chem 2007;282: 23337-23347. doi:10.1074/jbc.M700194200.

7. Rygiel KA, Robertson H, Marshall HL, Pekalski M, Zhao L, Booth TA, et al. Epithelial-mesenchymal transition contributes to portal tract fibrogenesis during human chronic liver disease. Lab Invest 2008;88:112-123. doi:10.1038/labinvest.3700704.

8. Fiorucci S, Rizzo G, Antonelli E, Renga B, Mencarelli A, Riccardi L, et al. Cross-talk between farnesoid-X-receptor (FXR) and 
peroxisome proliferator-activated receptor gamma contributes to the antifibrotic activity of FXR ligands in rodent models of liver cirrhosis. J Pharmacol Exp Ther 2005;315:58-68. doi:10.1124/ jpet.105.085597.

9. Iredale JP, Benyon RC, Pickering J, McCullen M, Northrop M, Pawley S, et al. Mechanisms of spontaneous resolution of rat liver fibrosis. Hepatic stellate cell apoptosis and reduced hepatic expression of metalloproteinase inhibitors. J Clin Invest 1998;102:538-549. doi:10.1172/JCI1018.

10. Pahl HL, Krauss B, Schulze-Osthoff K, Decker T, Traenckner $\mathrm{EB}$, Vogt $\mathrm{M}$, et al. The immunosuppressive fungal metabolite gliotoxin specifically inhibits transcription factor NF-kappaB. J Exp Med 1996;183:1829-1840. doi:10.1084/jem.183.4.1829.

11. Wright MC, Issa R, Smart DE, Trim N, Murray GI, Primrose JN, et al. Gliotoxin stimulates the apoptosis of human and rat hepatic stellate cells and enhances the resolution of liver fibrosis in rats. Gastroenterology 2001;121:685-698. doi:10.1053/gast.2001.27188.

12. Orr JG, Leel V, Cameron GA, Marek CJ, Haughton EL, Elrick $\mathrm{LJ}$, et al. Mechanism of action of the antifibrogenic compound gliotoxin in rat liver cells. Hepatology 2004;40:232-242. doi: 10.1002/hep. 20254.

13. Beljaars L, Weert B, Geerts A, Meijer DK, Poelstra K. The preferential homing of a platelet derived growth factor receptorrecognizing macromolecule to fibroblast-like cells in fibrotic tissue. Biochem Pharmacol 2003;66:1307-1317. doi:10.1016/ S0006-2952(03)00445-3.

14. Beljaars L, Molema G, Schuppan D, Geerts A, De Bleser PJ, Weert B, et al. Successful targeting to rat hepatic stellate cells using albumin modified with cyclic peptides that recognize the collagen type VI receptor. J Biol Chem 2000;275:12743-12751. doi:10.1074/jbc.275.17.12743.

15. Beljaars L, Molema G, Weert B, Bonnema H, Olinga P, Groothuis GM, et al. Albumin modified with mannose 6-phosphate: a potential carrier for selective delivery of antifibrotic drugs to rat and human hepatic stellate cells. Hepatology 1999;29:14861493. doi:10.1002/hep. 510290526.

16. Elrick LJ, Leel V, Blaylock MG, Duncan L, Drever MR, Strachan $\mathrm{G}$, et al. Generation of a monoclonal human single chain antibody fragment to hepatic stellate cells - a potential mechanism for targeting liver anti-fibrotic therapeutics. J Hepatol 2005;42:888896. doi:10.1016/j.jhep. 2005.01.028.

17. Cassiman D, van Pelt J, De Vos R, Van Lommel F, Desmet V, Yap SH, et al. Synaptophysin: a novel marker for human and rat hepatic stellate cells. Am J Pathol 1999;155:1831-1839.

18. McMahon HT, Bolshakov VY, Janz R, Hammer RE, Siegelbaum SA, Südhof TC. Synaptophysin, a major synaptic vesicle protein, is not essential for neurotransmitter release. Proc Natl Acad Sci USA 1996;93:4760-4764. doi:10.1073/pnas.93.10.4760.

19. Clackson T, Hoogenboom HR, Griffiths AD, Winter G. Making antibody fragments using phage display libraries. Nature 1991;352:624-628. doi:10.1038/352624a0.

20. Brissette R, Goldstein NI. The use of phage display peptide libraries for basic and translational research. Methods Mol Biol 2007;383:203-213.

21. Douglass A, Wallace K, Parr R, Park J, Durward E, Broadbent I, et al. Antibody-targeted myofibroblast apoptosis reduces fibrosis during sustained liver injury. J Hepatol 2008;49:88-98.

22. Elsharkawy AM, Wright MC, Hay RT, Arthur MJ, Hughes T, Bahr MJ, et al. Persistent activation of nuclear factor-kappaB in cultured rat hepatic stellate cells involves the induction of potentially novel Rel-like factors and prolonged changes in the expression of IkappaB family proteins. Hepatology 1999;30:761769. doi:10.1002/hep. 510300327.

23. Hagens WI, Olinga P, Meijer DK, Groothuis GM, Beljaars L, Poelstra K. Gliotoxin non-selectively induces apoptosis in fibrotic and normal livers. Liver Int 2006;26:232-239. doi:10.1111/j. 1478-3231.2005.01212.x.

24. Anselmi K, Stolz DB, Nalesnik M, Watkins SC, Kamath R, Gandhi CR. Gliotoxin causes apoptosis and necrosis of rat $\mathrm{Ku}-$ pffer cells in vitro and in vivo in the absence of oxidative stress: exacerbation by caspase and serine protease inhibition. J Hepatol 2007;47:103-113. doi:10.1016/j.jhep. 2007.02.024.

25. Duffield JS, Forbes SJ, Constandinou CM, Clay S, Partolina M, Vuthoori S, et al. Selective depletion of macrophages reveals distinct, opposing roles during liver injury and repair. J Clin Invest 2005;115:56-65.

26. Rosenberg WM, Voelker M, Thiel R, Becka M, Burt A, Schuppan $\mathrm{D}$, et al. Serum markers detect the presence of liver fibrosis: a cohort study. Gastroenterology 2004;127:1704-1713. doi: 10.1053/j.gastro.2004.08.052.

27. Rockey DC, Bissell DM. Noninvasive measures of liver fibrosis. Hepatology 2006;43:S113-S120. doi:10.1002/hep. 21046.

28. Fowell AJ, Iredale JP. Emerging therapies for liver fibrosis. Dig Dis 2006;24:174-183. doi:10.1159/000090320.

29. Cortez-Pinto H, Camilo ME. Non-alcoholic fatty liver disease/nonalcoholic steatohepatitis (NAFLD/NASH): diagnosis and clinical course. Best Pract Res Clin Gastroenterol 2004;18:1089-1104.

30. World Health Organisation. http://www.who.int/mediacentre/ factsheets/fs164/en/. Accessed Oct 2000.

31. Kim KY, Rhim T, Choi I, Kim SS. N-acetylcysteine induces cell cycle arrest in hepatic stellate cells through its reducing activity. J Biol Chem 2001;276:40591-40598. doi:10.1074/jbc.M100975200.

32. Kawada N, Seki S, Inoue M, Kuroki T. Effect of antioxidants, resveratrol, quercetin, and $\mathrm{N}$-acetylcysteine, on the functions of cultured rat hepatic stellate cells and Kupffer cells. Hepatology 1998;27:1265-1274. doi:10.1002/hep. 510270512.

33. Ke Z, Zhou F, Wang L, Chen S, Liu F, Fan X, et al. Downregulation of Wnt signaling could promote bone marrow-derived mesenchymal stem cells to differentiate into hepatocytes. Biochem Biophys Res Commun 2008;367:342-348.

34. Kordes C, Sawitza I, Häussinger D. Canonical Wnt signaling maintains the quiescent stage of hepatic stellate cells. Biochem Biophys Res Commun 2008;367:116-123. doi:10.1016/j.bbrc.2007. 12.085 .

35. Cheng JH, She H, Han YP, Wang J, Xiong S, Asahina K, et al. Wnt antagonism inhibits hepatic stellate cell activation and liver fibrosis. Am J Physiol Gastrointest Liver Physiol 2008;294:G39G49. doi:10.1152/ajpgi.00263.2007.

36. Houglum K, Venkataramani A, Lyche K, Chojkier M. A pilot study of the effects of d-alpha-tocopherol on hepatic stellate cell activation in chronic hepatitis C. Gastroenterology 1997;113: 1069-1073. doi:10.1053/gast.1997.v113.pm9322499.

37. Harrison SA, Torgerson S, Hayashi P, Ward J, Schenker S. Vitamin $\mathrm{E}$ and vitamin $\mathrm{C}$ treatment improves fibrosis in patients with nonalcoholic steatohepatitis. Am J Gastroenterol 2003;98: 2485-2490. doi:10.1111/j.1572-0241.2003.08699.x.

38. Bataller R, Schwabe RF, Choi YH, Yang L, Paik YH, Lindquist J, et al. NADPH oxidase signal transduces angiotensin II in hepatic stellate cells and is critical in hepatic fibrosis. J Clin Invest 2003;112:1383-1394.

39. Ishibashi H, Komori A, Shimoda S, Gershwin ME. Guidelines for therapy of autoimmune liver disease. Semin Liver Dis 2007;27:214-226. doi:10.1055/s-2007-979472.

40. Friedman SL. Liver fibrosis-from bench to bedside. J Hepatol 2003;38:S38-S53. doi:10.1016/S0168-8278(02)00429-4.

41. Bolkenius U, Hahn D, Gressner AM, Breitkopf K, Dooley S, Wickert L. Glucocorticoids decrease the bioavailability of TGFbeta which leads to a reduced TGF-beta signaling in hepatic stellate cells. Biochem Biophys Res Commun 2004;325:12641270. doi:10.1016/j.bbrc.2004.10.164. 
42. Melgert BN, Olinga P, Van Der Laan JM, Weert B, Cho J, Schuppan D, et al. Targeting dexamethasone to Kupffer cells: effects on liver inflammation and fibrosis in rats. Hepatology 2001;34:719-728. doi:10.1053/jhep. 2001.27805.

43. Yamamoto H, Kondo M, Nakamori S, Nagano H, Wakasa K, Sugita $\mathrm{Y}$, et al. JTE-522, a cyclooxygenase-2 inhibitor, is an effective chemopreventive agent against rat experimental liver fibrosis. Gastroenterology 2003;125:556-571. doi:10.1016/S0016-5085 (03)00904-1.

44. Yu J, Wu CW, Chu ES, Hui AY, Cheng AS, Go MY, et al. Elucidation of the role of COX-2 in liver fibrogenesis using transgenic mice. Biochem Biophys Res Commun 2008;372:571577.

45. Oakley F, Meso M, Iredale JP, Green K, Marek CJ, Zhou X, et al. Inhibition of inhibitor of kappaB kinases stimulates hepatic stellate cell apoptosis and accelerated recovery from rat liver fibrosis. Gastroenterology 2005;128:108-120. doi:10.1053/j.gastro.2004. 10.003 .

46. Galli A, Crabb DW, Ceni E, Salzano R, Mello T, SvegliatiBaroni G, et al. Antidiabetic thiazolidinediones inhibit collagen synthesis and hepatic stellate cell activation in vivo and in vitro. Gastroenterology 2002;122:1924-1940. doi:10.1053/gast.2002. 33666.

47. Marra F, Efsen E, Romanelli RG, Caligiuri A, Pastacaldi S, Batignani $\mathrm{G}$, et al. Ligands of peroxisome proliferator-activated receptor gamma modulate profibrogenic and proinflammatory actions in hepatic stellate cells. Gastroenterology 2000;119:466478. doi:10.1053/gast.2000.9365.

48. Lin J, Chen A. Activation of peroxisome proliferator-activated receptor-gamma by curcumin blocks the signaling pathways for PDGF and EGF in hepatic stellate cells. Lab Invest 2008;88:529_ 540. doi:10.1038/labinvest.2008.20.

49. Kliewer SA, Willson TM. Regulation of xenobiotic and bile acid metabolism by the nuclear pregnane $\mathrm{X}$ receptor. J Lipid Res 2002;43:359-364.

50. Marek CJ, Tucker SJ, Konstantinou DK, Elrick LJ, Haefner D, Sigalas C, et al. Pregnenolone-16alpha-carbonitrile inhibits rodent liver fibrogenesis via PXR (pregnane $\mathrm{X}$ receptor)-dependent and PXR-independent mechanisms. Biochem J 2005;387: 601-608. doi:10.1042/BJ20041598.

51. Haughton EL, Tucker SJ, Marek CJ, Durward E, Leel V, Bascal $Z$, et al. Pregnane $\mathrm{X}$ receptor activators inhibit human hepatic stellate cell transdifferentiation in vitro. Gastroenterology 2006; 131:194-209. doi:10.1053/j.gastro.2006.04.012.

52. Podesta A, Lopez P, Terg R, Villamil F, Flores D, Mastai R, et al. Treatment of pruritus of primary biliary cirrhosis with rifampin. Dig Dis Sci 1991;36:216-220. doi:10.1007/BF01300759.

53. Khurana S, Singh P. Rifampin is safe for treatment of pruritus due to chronic cholestasis: a meta-analysis of prospective randomized-controlled trials. Liver Int 2006;26:943-948. doi:10.1111/ j.1478-3231.2006.01326.x.

54. Schuetz EG, Strom S, Yasuda K, Lecureur V, Assem M, Brimer $\mathrm{C}$, et al. Disrupted bile acid homeostasis reveals an unexpected interaction among nuclear hormone receptors, transporters, and cytochrome P450. J Biol Chem 2001;276:39411-39418. doi: 10.1074/jbc.M106340200.

55. Angulo P, Batts KP, Therneau TM, Jorgensen RA, Dickson ER, Lindor KD. Long-term ursodeoxycholic acid delays histological progression in primary biliary cirrhosis. Hepatology 1999;29: 644-647. doi:10.1002/hep. 510290301.

56. Yoshiji H, Kuriyama S, Fukui H. Blockade of renin-angiotensin system in antifibrotic therapy. J Gastroenterol Hepatol 2007;22: S93-S95. doi:10.1111/j.1440-1746.2006.04663.x.

57. Wei HS, Lu HM, Li DG, Zhan YT, Wang ZR, Huang X, et al. The regulatory role of AT 1 receptor on activated HSCs in hepatic fibrogenesis:effects of RAS inhibitors on hepatic fibrosis induced by $\mathrm{CCl}_{4}$. World J Gastroenterol 2000;6:824-828.

58. Sookoian S, Fernández MA, Castaño G. Effects of six months losartan administration on liver fibrosis in chronic hepatitis C patients: a pilot study. World J Gastroenterol 2005;11:75607563.

59. Yoshiji H, Kuriyama S, Yoshii J, Ikenaka Y, Noguchi R, Nakatani T, et al. Angiotensin-II type 1 receptor interaction is a major regulator for liver fibrosis development in rats. Hepatology 2001;34:745-750.

60. Peterson TC. Pentoxifylline prevents fibrosis in an animal model and inhibits platelet-derived growth factor-driven proliferation of fibroblasts. Hepatology 1993;17:486-493.

61. Desmoulière A, Xu G, Costa AM, Yousef IM, Gabbiani G, Tuchweber B. Effect of pentoxifylline on early proliferation and phenotypic modulation of fibrogenic cells in two rat models of liver fibrosis and on cultured hepatic stellate cells. J Hepatol 1999;30:621-631. doi:10.1016/S0168-8278(99)80192-5.

62. Nicholson CD, Challiss RA, Shahid M. Differential modulation of tissue function and therapeutic potential of selective inhibitors of cyclic nucleotide phosphodiesterase isoenzymes. Trends Pharmacol Sci 1991;12:19-27. doi:10.1016/0165-6147(91)904 84-A.

63. Lee KS, Cottam HB, Houglum K, Wasson DB, Carson D, Chojkier M. Pentoxifylline blocks hepatic stellate cell activation independently of phosphodiesterase inhibitory activity. Am J Physiol 1997;273:G1094-G1100.

64. Liu P, Liu CH, Wang HN, Hu YY, Liu C. Effect of salvianolic acid $\mathrm{B}$ on collagen production and mitogen-activated protein kinase activity in rat hepatic stellate cells. Acta Pharmacol Sin 2002;23:733-738.

65. Luk JM, Wang X, Liu P, Wong KF, Chan KL, Tong Y, et al. Traditional Chinese herbal medicines for treatment of liver fibrosis and cancer: from laboratory discovery to clinical evaluation. Liver Int 2007;27:879-890. doi:10.1111/j.1478-3231.2007. 01527.x.

66. Liu P, Hu YY, Liu C, Zhu DY, Xue HM, Xu ZQ, et al. Clinical observation of salvianolic acid $\mathrm{B}$ in treatment of liver fibrosis in chronic hepatitis B. World J Gastroenterol 2002;8:679-685.

67. Di Sario A, Bendia E, Svegliati Baroni G, Ridolfi F, Casini A, Ceni E, et al. Effect of pirfenidone on rat hepatic stellate cell proliferation and collagen production. J Hepatol 2002;37:584591. doi:10.1016/S0168-8278(02)00245-3.

68. Pines M, Knopov V, Genina O, Lavelin I, Nagler A. Halofuginone, a specific inhibitor of collagen type I synthesis, prevents dimethylnitrosamine-induced liver cirrhosis. J Hepatol 1997;27: 391-398. doi:10.1016/S0168-8278(97)80186-9.

69. Popov Y, Patsenker E, Bauer M, Niedobitek E, Schulze-Krebs A, Schuppan D. Halofuginone induces matrix metalloproteinases in rat hepatic stellate cells via activation of p38 and NFkappaB. J Biol Chem 2006;281:15090-15098. doi:10.1074/jbc.M600030200.

70. Teixeira-Clerc F, Julien B, Grenard P, Tran Van Nhieu J, Deveaux V, Li L, et al. CB1 cannabinoid receptor antagonism: a new strategy for the treatment of liver fibrosis. Nat Med 2006;12:671-676. doi:10.1038/nm1421.

71. Julien B, Grenard P, Teixeira-Clerc F, Van Nhieu JT, Li L, Karsak M, et al. Antifibrogenic role of the cannabinoid receptor CB2 in the liver. Gastroenterology 2005;128:742-755. doi: 10.1053/j.gastro.2004.12.050.

72. Hézode C, Roudot-Thoraval F, Nguyen S, Grenard P, Julien B, Zafrani ES, et al. Daily cannabis smoking as a risk factor for progression of fibrosis in chronic hepatitis C. Hepatology 2005;42:63-71. doi:10.1002/hep. 20733.

73. Ebrahimkhani MR, Kiani S, Oakley F, Kendall T, Shariftabrizi A, Tavangar SM, et al. Naltrexone, an opioid receptor antagonist, 
attenuates liver fibrosis in bile duct ligated rats. Gut 2006;55: 1606-1616. doi:10.1136/gut.2005.076778.

74. Ruddell RG, Oakley F, Hussain Z, Yeung I, Bryan-Lluka LJ, Ramm GA, et al. A role for serotonin (5-HT) in hepatic stellate cell function and liver fibrosis. Am J Pathol 2006;169:861-876. doi:10.2353/ajpath.2006.050767.

75. Anan A, Baskin-Bey ES, Bronk SF, Werneburg NW, Shah VH, Gores GJ. Proteasome inhibition induces hepatic stellate cell apoptosis. Hepatology 2006;43:335-344. doi:10.1002/hep. 21036.

76. Novo E, Marra F, Zamara E, Valfrè di Bonzo L, Monitillo L, Cannito $\mathrm{S}$, et al. Overexpression of Bcl-2 by activated human hepatic stellate cells: resistance to apoptosis as a mechanism of progressive hepatic fibrogenesis in humans. Gut 2006;55:11741182. doi:10.1136/gut.2005.082701.

77. Buck M, Chojkier M. A ribosomal S-6 kinase-mediated signal to C/EBP-beta is critical for the development of liver fibrosis. PLoS ONE. 2007;2:e1372. doi:10.1371/journal.pone.0001372.

78. George J, Roulot D, Koteliansky VE, Bissell DM. In vivo inhibition of rat stellate cell activation by soluble transforming growth factor beta type II receptor: a potential new therapy for hepatic fibrosis. Proc Natl Acad Sci USA 1999;96:12719-12724. doi:10.1073/pnas.96.22.12719.

79. Derynck R, Akhurst RJ, Balmain A. TGF-beta signaling in tumor suppression and cancer progression. Nat Genet 2001;29:117-129. doi:10.1038/ng1001-117.

80. Okuno M, Akita K, Moriwaki H, Kawada N, Ikeda K, Kaneda K, et al. Prevention of rat hepatic fibrosis by the protease inhibitor, camostat mesilate, via reduced generation of active TGF-beta. Gastroenterology 2001;120:1784-1800. doi:10.1053/gast.2001. 24832.

81. Gnainsky Y, Kushnirsky Z, Bilu G, Hagai Y, Genina O, Volpin $\mathrm{H}$, et al. Gene expression during chemically induced liver fibrosis: effect of halofuginone on TGF-beta signaling. Cell Tissue Res 2007;328:153-166. doi:10.1007/s00441-006-0330-1.

82. Sugino H, Kumagai N, Watanabe S, Toda K, Takeuchi O, Tsunematsu $\mathrm{S}$, et al. Polaprezinc attenuates liver fibrosis in a mouse model of non-alcoholic steatohepatitis. J Gastroenterol Hepatol 2008; In press.

83. Brocks B, Kraft S, Zahn S, Noll S, Pan C, Schauer M, et al. Generation and optimization of human antagonistic antibodies against TIMP-1 as potential therapeutic agents in fibrotic diseases. Hum Antibodies 2006;15:115-124.

84. Salgado S, Garcia J, Vera J, Siller F, Bueno M, Miranda A, et al. Liver cirrhosis is reverted by urokinase-type plasminogen activator gene therapy. Mol Ther 2000;2:545-551. doi:10.1006/ mthe.2000.0210.

85. Ohayon O, Mawasi N, Pevzner A, Tryvitz A, Gildor T, Pines M, et al. Halofuginone upregulates the expression of heparinase in thioacetamide-induced liver fibrosis in rats. Lab Invest 2008; 88:627-633.

86. Kamada Y, Tamura S, Kiso S, Matsumoto H, Saji Y, Yoshida Y, et al. Enhanced carbon tetrachloride-induced liver fibrosis in mice lacking adiponectin. Gastroenterology 2003;125:1796-1807. doi: 10.1053/j.gastro.2003.08.029.

87. Potter JJ, Womack L, Mezey E, Anania FA. Transdifferentiation of rat hepatic stellate cells results in leptin expression. Biochem Biophys Res Commun 1998;244:178-182. doi:10.1006/bbrc. 1997.8193.

88. Ikejima K, Honda H, Yoshikawa M, Hirose M, Kitamura T, Takei $\mathrm{Y}$, et al. Leptin augments inflammatory and profibrogenic responses in the murine liver induced by hepatotoxic chemicals. Hepatology 2001;34:288-297. doi:10.1053/jhep. 2001.26518. 